\title{
Coral mortality associated with dinoflagellate blooms in the eastern Pacific (Costa Rica and Panama)
}

\author{
Héctor M. Guzmán ${ }^{1}$, Jorge Cortés ${ }^{2,}$, Peter W. Glynn², Robert H. Richmond ${ }^{3}$ \\ ${ }^{1}$ Smithsonian Tropical Research Institute (Panamá), APO Miami, Florida 34002-0011, USA \\ ${ }^{2}$ Division of Biology and Living Resources, Rosenstiel School of Marine and Atmospheric Science, University of Miami, 4600 Rickenbacker \\ Causeway, Miami, Florida 33149-1098, USA \\ ${ }^{3}$ Marine Laboratory, University of Guam, UOG Station, Mangilao, Guam 96923, USA
}

\begin{abstract}
Coral reefs at Caño Island, Costa Rica, and Uva lsland. Panamá, were affected during severe dinoflagellate blooms in 1985. In the second half of 1985, mass mortality of reef fishes and invertebrates, especially reef corals, occurred during blooms of the dinoflagellates Cochlodinium catenatum and Gonyaulax monilata. At Caño Island, up to $100 \%$ coral mortality was observed between the surface and $3 \mathrm{~m}$ depth, with pocilloporid species and Tubastrea coccinea most severely affected. At Uva Island, only $13 \%$ pocilloporid mortality occurred and this was confined to the shallowest reef areas $(\leq 3 \mathrm{~m})$. The copious amounts of mucus associated with $C$ catenatum, present in the water column to $1-3 \mathrm{~m}$ depth, and adhering to coral colonies, suggested that coral death was caused by smothering. Other conditions that may have affected reef organisms were the presence of toxic $G$. monilata, and possible oxygen depletion due to the high densities of phytoplankton and the decomposition of dead organisms. These dinoflagellate blooms have interfered with recovery of reefs disturbed during the 1982/83 El Niño warming event.
\end{abstract}

There are only 2 reports of coral death associated with phytoplankton blooms. Baas-Becking (1951) reported on the death of corals in the shallow waters of New Caledonia, and attributed this to the putrefaction of thick masses of Trichodesmium thiebautii causing a marked reduction in dissolved oxygen. Smith (1975) commented on the impact of a 1971 'red tide' on reef coral communities off the west coast of Florida, USA, with near-complete mortality of shallow-water $(<40 \mathrm{~m}$ ) biotas over extensive areas. Smith hypothesized these mortalities were caused by bacterial and fungal infec-

\footnotetext{
- Permanent address: Centro de Investigación en Ciencias del Mar y Limnologia (CIMAR), Universidad de Costa Rica, San Pedro, Costa Rica
}

tions, oxygen depletion, and hydrogen sulfide poisoning rather than by toxins of Ptychodiscus brevis (Davis) that were present during the event.

In this note we present observations of coral death associated with dinoflagellate blooms in the eastern Pacific - at Caño Island, Costa Rica and Uva Island, Panamá - and discuss possible mechanisms that may have resulted in coral death.

Study site and methods. Caño Island $\left(8^{\circ} 43^{\prime} \mathrm{N}\right.$, $83^{\circ} 52^{\prime} \mathrm{W}$ ) is situated in the southern region of the Pacific coast of Costa Rica, ca $15 \mathrm{~km}$ offshore (Fig. 1). Information on the coral community structure and climatic and oceanographic conditions is available in Guzmán \& Cortés (1989a, b). The percentage of dead colonies of all coral species encountered at Caño Island in July 1985 was recorded. Eight permanent plots of $10 \mathrm{~m}^{2}$ each at 4 localities from 0.5 to $12 \mathrm{~m}$ depth that have been surveyed since January 1984 (for an assessment of coral recovery after the 1982/83 El Niño event) were mapped in January 1985 before the dinoflagellate bloom and in late August 1985 near the end of the bloom. Water around the reefs was collected using $1 \mathrm{l}$ bottles in July 1985 and the species composition and relative abundances of the phytoplankters were determined using a Palmer-Maloney chamber (Steidinger 1979).

Uva Island reef $\left(7^{\circ} 49^{\prime} \mathrm{N}, 81^{\circ} 46^{\prime} \mathrm{W}\right)$ is located about $40 \mathrm{~km}$ offshore in the Gulf of Chiriquí, Panamá, with similar climatic conditions to those at Caño Island. Detailed information on the oceanographic conditions and coral community structure are available in Dana (1975) and Glynn (1976). The same scleractinian corals occur in both study areas; however, at Uva Island the 


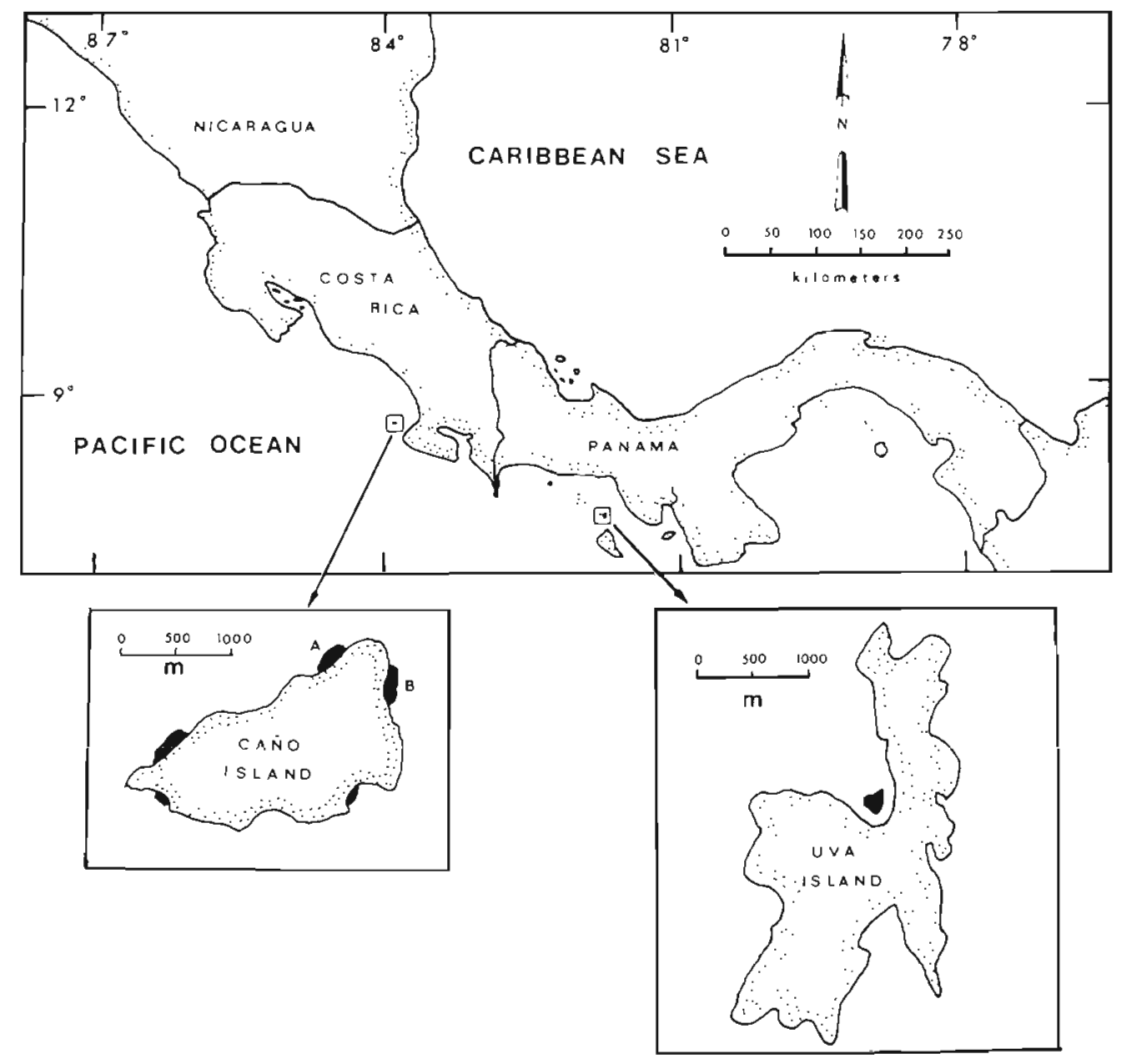

Fig. 1. Southern Central America, with detail of the islands studied: Caño Island, Costa Rica $\left(8^{\circ} 43^{\prime} \mathrm{N}, 83^{\circ} 52^{\prime} \mathrm{W}\right)$ and Uva Island, Gulf of Chiriquí, Panamá $\left(7^{\circ} 49^{\prime} \mathrm{N}, 81^{\circ} 46^{\prime} \mathrm{W}\right)$. Shaded areas are the coral reefs, at Cano Island $\mathrm{A}=$ north site and $\mathrm{B}=$ east site

Table 1 Percent of dead coral colonies observed on 25 July 1985, durng the dinoflagellate bloom at Caño Island, Costa Rica

\begin{tabular}{|c|c|c|c|c|}
\hline Taxon & Area & $\begin{array}{l}\text { Depth } \\
(\mathrm{m})\end{array}$ & $\begin{array}{l}\text { No. colonies } \\
\text { examined }\end{array}$ & Dead \\
\hline $\begin{array}{l}\text { Pocillopora spp. } \\
\text { (predominantly } P \text {. elegans) }\end{array}$ & $\begin{array}{l}\text { East } \\
\text { North }\end{array}$ & $\begin{array}{c}0.5-1 \\
2 \\
2-4 \\
3-6 \\
10-25 \\
0.5-1 \\
1-2 \\
2-8\end{array}$ & $\begin{array}{r}175 \\
15 \\
96 \\
34 \\
71 \\
18 \\
5 \\
9\end{array}$ & $\begin{array}{r}100 \\
96 \\
94 \\
91 \\
1 \\
83 \\
0 \\
100\end{array}$ \\
\hline Porites lobata & $\begin{array}{l}\text { East } \\
\text { North }\end{array}$ & $\begin{array}{c}0.5-1 \\
3-10 \\
1-2 \\
2-8\end{array}$ & $\begin{array}{r}13 \\
1.9 \\
9 \\
7\end{array}$ & $\begin{array}{l}0 \\
8 \\
0 \\
0\end{array}$ \\
\hline Gardineroseris planulata & $\begin{array}{l}\text { East } \\
\text { North }\end{array}$ & $\begin{array}{l}5 \\
2-5\end{array}$ & $\begin{array}{l}1 \\
3\end{array}$ & $\begin{array}{l}0 \\
0\end{array}$ \\
\hline Pavona clavus & $\begin{array}{l}\text { East } \\
\text { North }\end{array}$ & $\begin{array}{l}1-1.5 \\
2-5\end{array}$ & $\begin{array}{l}3 \\
9\end{array}$ & $\begin{array}{l}0 \\
0\end{array}$ \\
\hline Pavona gigantea & North & $2-5$ & 6 & 0 \\
\hline Tubastrea coccinea & East & $\begin{array}{l}2-10 \\
10 \\
10\end{array}$ & $\begin{array}{l}95 \\
21 \\
17\end{array}$ & $\begin{array}{r}95 \\
0 \\
50\end{array}$ \\
\hline
\end{tabular}


relative abundance of pocilloporid corals is higher than at Caño Island. Ten permanent chain transects, between 3 and $6 \mathrm{~m}$ depth, were sampled at Uva Island 3 mo before and 2 mo after the dinoflagellate bloom. The chain transects were $10 \mathrm{~m}$ long with 73 sampling points (links) $\mathrm{m}^{-1}$ and the distance covered by each species was recorded (Glynn 1984). The dinoflagellates at Uva Island were not identified to species.

Results. A severe dinoflagellate bloom, or succession of blooms, occurred around Caño Island from 3 June to 12 July 1985, with additional pulses through October (park rangers daily report, Caño Island Biological Reserve). Surface waters, from 2 to $3 \mathrm{~m}$ depth, were red-yellow with viscous foam presumably produced by the dinoflagellates. A surface water sample collected at Caño Island in July 1985 contained $8.3 \times 10^{5}$ live phytoplankton cells $1^{-1}$ and more than $3 \times 10^{6} \mathrm{cells}^{-1}$ including dead cells. The relative abundances by cell number were: Cochlodinium catenatum Okamura $(97.0 \%)$, Gonyaulax monilata Howell $(1.4 \%)$, diatoms $(1.2 \%)$ and other dinoflagellates $(0.4 \%)$. Numerous fish were affected, with hundreds of scarids, balistids, acanthurids, pomacentrids and tetraodontids found dead on the beach, as well as dead hermit crabs, brachyuran crabs and gastropods. Some shallow water corals were also affected (Table 1), especially Pocillopora elegans Dana, P. damicornis (Linnaeus) and the azooxanthellate coral Tubastrea coccinea Lesson. The presence of live obligate crustacean symbiotes in some dead pocilloporid corals indicated recent mortality. A significant inverse relation was found between the number of dead colonies and depth $(\operatorname{tau}=-0.923, \mathrm{p}$ $<0.03, \mathrm{n}=20$, Kendall rank correlation). No recently dead or partially dead corals were observed in deeper waters ( $\geq 10 \mathrm{~m}$ ).

Between January and August 1985, the percentage cover of live pocilloporid corals in the permanent plots at Caño Island decreased to zero at the shallow stations
(0.5 to $3 \mathrm{~m}$ depth), while the massive corals remained unchanged (Table 2). The deeper stations (6 to $12 \mathrm{~m}$ depth) showed no significant change in live coral cover between January and August 1985 (Table 2).

The Uva Island dinoflagellate bloom was observed in October and November 1985. It had a red-brown color and probably lasted several days. Numerous pocilloporid corals at 1 to $2 \mathrm{~m}$ depth had bleached and were sloughing tissues. The co-occurrence of viscous foam and dinoflagellates suggested that the former was produced by the latter. The viscous foam near the surface oscillated vertically with the tides over shallow-water corals, which were most affected. Transect sampling 3 mo before the dinoflagellate bloom and 2 mo after indicated minor coral mortality in the shallowest transects $(3 \mathrm{~m})$. In 4 transects at $3 \mathrm{~m}$ depth, cover of live Pocillopora spp. was reduced by $12.8 \%$ (Table 3 ), but the decline was not statistically significant. The increases in coral cover in the deeper transects (Table 3, Transects 5 to 8 ) were due to fragmentation and the spread of live branches into the sampling area. Reductions also resulted from coral fragmentation and the transport of pocilloporid corals away from a transect (Table 3, Transect 9) and the burial of massive corals by dead pocilloporid branches (Table 3, Transect 10).

Discussion. The 1985 dinoflagellate bloom was the most severe reported off the Pacific coast of Costa Rica during the last $15 \mathrm{yr}$ (R. Víquez pers. comm. 1988). Intense upwellings were experienced that year in the Gulf of Panamá, which were related to anti-El Niño type activity (Glynn 1989). These conditions could have caused a general shoaling of the nutricline in nonupwelling areas, ultimately leading to the dinoflagellate bloom observed in 1985.

In previous years at the Gulf of Nicoya, less than $100 \mathrm{~km}$ northwest of Caño Island, blooms were also dominated by Cochlodinium catenatum, according to Hargraves \& Víquez $(1981,1985)$. This species has not

Table 2. Percent live hermatypic coral cover before and after a dinoflagellate bloom in $10 \mathrm{~m}^{2}$ plots, Caño Island, Costa Rica. Pocilloporid corals were Pocillopora elegans and Pocillopora damicornis; other corals were Pavona varians, Pavona gigantea, Pavona clavus, Psammocora stellata, Gardineroseris planulata and Porites lobata

\begin{tabular}{|cccccc|}
\hline $\begin{array}{l}\text { Plot } \\
\text { no. }\end{array}$ & $\begin{array}{c}\text { Depth } \\
(\mathrm{m})\end{array}$ & Pocilloporid corals & All corals & Pocilloporid corals & All corals \\
\hline 1 & $0.5-1$ & 24.19 & 29 August 1985 & 3.35 \\
2 & $0.5-1$ & 30.19 & 30.81 & 0 & 1.73 \\
3 & $2-3$ & 34.60 & 37.50 & 0 & 2.61 \\
4 & $2-3$ & 36.90 & 40.40 & 0 & 3.39 \\
5 & 6 & 0 & 30.40 & 0 & 27.47 \\
6 & 6 & 0 & 31.57 & 0 & 27.50 \\
7 & $10-12$ & 5.13 & 25.48 & $4.25^{\text {a }}$ & 23.35 \\
8 & $10-12$ & 5.31 & 20.16 & $4.91^{\text {a }}$ & 16.54 \\
& & & & \\
\hline
\end{tabular}


Table 3. Percent live hermatypic coral cover before and after a phytoplankton bloom, Uva Island, Gulf of Chiriquí, Panamá. Pocilloporid corals were Pocillopora damicornis and P. elegans; other corals were Gardineroseris planulata, Pavona varians and Psammocora stellata

\begin{tabular}{|c|c|c|c|c|c|}
\hline \multirow{2}{*}{$\begin{array}{l}\text { Transect } \\
\text { no. }\end{array}$} & \multirow{2}{*}{$\begin{array}{l}\text { Depth } \\
(\mathrm{m})\end{array}$} & \multicolumn{2}{|c|}{13 August 1985} & \multicolumn{2}{|c|}{18 January 1986} \\
\hline & & Pocilloporid corals & All corals & Pocilloporid corals & All corals \\
\hline 1 & 3 & 25.9 & 25.9 & 20.7 & 20.7 \\
\hline 2 & 3 & 21.5 & 21.5 & 21.0 & 21.0 \\
\hline 3 & 3 & 23.6 & 23.6 & 20.6 & 20.6 \\
\hline 4 & 3 & 22.5 & 22.9 & 18.9 & 18.9 \\
\hline 5 & 4 & 36.8 & 37.1 & 40.8 & 42.0 \\
\hline 6 & 4 & 19.3 & 19.7 & 23.8 & 24.1 \\
\hline 7 & 5 & 14.7 & 14.7 & 20.8 & 20.8 \\
\hline 8 & 5 & 23.7 & 25.8 & 24.9 & 25.5 \\
\hline 9 & 5 & 14.4 & 14.4 & 8.5 & 8.5 \\
\hline 10 & 6 & 0 & 27.1 & 0 & 19.7 \\
\hline
\end{tabular}

been proven to be toxic, but other species of Cochlodinium were toxic to fish in Japan (Yuki \& Yoshimatsu 1989). Even though concentrations of dinoflagellates during those blooms were higher than at Caño Island, Hargraves \& Víquez $(1981,1985)$ did not report any massive mortality in the estuarine Gulf of Nicoya. This difference in mortality between Nicoya and Caño may have been due to a greater susceptibility of corals to changes in water quality than most estuarine organisms and because Gonyaulax monilata was not found at Nicoya.

The possible mechanisms by which phytoplankton blooms cause mortality include: (a) toxicity, (b) reduction of light penetration, (c) depletion of dissolved oxygen, (d) smothering by mucus, or (e) any combination of the above effects.

Mortality caused by toxic dinoflagellate blooms is well documented from boreal to tropical seas (Steidinger \& Baden 1984, Anderson et al. 1985). Of the dinoflagellates observed in the blooms, only Gonyaulax monilata is known to be toxic (Steidinger \& Baden 1984), but even at low densities its toxicity may cause the death of organisms (Schantz et al. 1975 in Steidinger 1983).

Light reduction during the dirioflagellate blooms did not seem to be critical in the death of corals. Two observations suggest this: (1) the azooxanthellate coral Tubastrea coccinea, which is not light dependent, was significantly affected; and (2) corals in deeper water were not affected.

Death of marine organisms attributed to anoxia after phytoplankton blooms has been reported in several marine habitats, including coral reefs (Baas-Becking 1951, Smith 1975) The majority of the fishes and crabs affected at Caño and Uva Islands were active, freeliving members of the epibenthos. Also, as oxygen levels in warm waters are often close to the lower tolerance limits of aerobic organisms (Johannes \&
Betzer 1975), oxygen stress may occur on reefs, especially in the presence of decomposing organisms.

An increase in viscosity of the water due to mucus produced by dinoflagellates has been suggested as a possible cause of death of fish (Jenkinson 1989). There are no reports of coral death attributed to smothering by thick mucous layers due to phytoplankton blooms. However, a thick layer of mucus could effectively isolate corals from their environment, preventing feeding, respiration and excretion, and if the blockage were prolonged, the coral would die. Also, some bacteria thrive in the mucus produced by corals and an increase in bacterial density could cause coral death by sulfide poisoning, oxygen depletion and attack of coral tissue by the bacteria (Ducklow \& Mitchell 1979, Paul et al. 1986)

Eastern Pacific coral reefs are recovering slowly from the 1982/83 El Niño warming event that caused mass coral mortalities in Panamá and Costa Rica (Glynn et al. 1988). The 1985 dinoflagellate blooms occurred less than 2 yr after this disturbance. At Uva Island, where the El Niño disturbance resulted in 70 to $95 \%$ coral mortality, few corals were affected by the dinoflagellate bloom except at shallow depths $(\leq 3 \mathrm{~m})$. At Caño Island, El Niño-associated coral mortality was lower, 25 to $75 \%$, but mortality due to the dinoflagellate bloom was high, completely eliminating some coral species from shallow reef zones.

In conclusion, the death of reef organisms at Caño and Uva Islands was possibly caused by a combination of (a) toxicity, (b) oxygen depletion, and (c) smothering by mucus produced during dinoflagellate blooms. Adhesion of mucus to polypal areas, and the interference with polyp expansion, seemed the most likely cause of mortality in corals. These dinoflagellate blooms, occurring 2 yr after the 1982/83 El Niño warming event, have slowed the recovery of these disturbed reefs. 
Acknowledgements. Research supported by NSF grant OCE 8415615 to P.W.G. We thank R. Viquez, Universidad Nacional, Heredia, Costa Rica, for the identification of dinoflagellates and L. Brand, J. Cubit, C. M. Eakin, P. Hallock, R. Viquez, G. M. Wellington and 3 anonymous reviewers for criticizing the manuscript.

\section{LITERATURE CITED}

Anderson, D. M., White, A. W., Baden, D. G. (eds.) (1985) Toxic dinoflagellates. Proceedings of the 3rd international conference on toxic dinoflagellates, St. Andrews, New Brunswick, Canada. Elsevier, New York

Baas-Becking, L. G. M. (1951). Notes on some Cyanophyceae of the Pacific Region. Proc. K. Ned. Akad. Wet. Ser. C 54: $213-225$

Dana, T F. (1975). Development of contemporary eastern Pacific coral reefs. Mar Biol. 33: 355-374

Ducklow, H. W., Mitchell, R. (1979). Bacterial populations and adaptations in the mucus layers on living corals. Limnol. Oceanogr 24: 715-725

Glynn, P. W (1976). Some physical and biological determinants of coral community structure in the eastern Pacific. Ecol. Monogr. 46: 431-456

Glynn, P. W. (1984). Widespread coral mortality and the 1982/ 83 El Niño warming event. Environ. Conserv. 11: 133-146

Glynn, P. W (1989). Coral mortality and disturbances to reef corals in the tropical eastern Pacific. In: Glynn, P. W. (ed.) Global ecological consequences of the 1982-1983 El NinoSouthern Oscillation. Elsevier, Amsterdam, p. 55-126

Glynn, P. W., Cortés, J., Guzmán, H. M., Richmond, R. H. (1988). El Nino (1982-83) associated coral mortality and relationship to sea surface temperature deviations in the tropical eastern Pacific. Proc. 6th int. Coral Reef Symp., Townsville, in press

Guzmán, H. M. Cortés, J. (1989a). Coral reef community structure at ('año Island, Pacific Costa Rica. P.S.Z.N.I. Mar Ecol. 10: 21-43

This note was presented by Professor R. P. M. Bak, Texel The Netherlands
Guzmán, H. M., Cortés, J. (1989b). Growth rates of eight species of scleractinian corals in the eastern Pacific (Costa Rica). Bull. mar. Sci. 44: 1186-1194

Hargraves, P. E., Viquez, R. (1981). The dinoflagellate red tide in Golfo de Nicoya, Costa Rica. Rev. Biol. Trop. 29 $31-38$

Hargraves, P. E. Viquez, R. (1985). Spatial and temporal distribution of phytoplankton in the Gulf of Nicoya, Costa Rica. Bull. mar, Sci. 37: 577-585

Jenkinson, 1. R. (1989). Increases in viscosity may kill fish in some blooms. In: Okaichi, T., Anderson, D. M., Nemoto, T (eds.) Red tides: biology, environmental science, and toxicology. Elsevier, New York, p. 435-438

Johannes, R. E., Betzer, S. B. (1975). Introduction: marine communities respond differently to pollution in the tropics than at higher latitudes. In: Ferguson-Wood, E. J., Johannes, R. E. (eds.) Tropical marine pollution. Elsevier, New York, p. 1-12

Paul, J. H., DeFlaun, M. F., Jeffrey, W H. (1986). Elevated levels of microbial activity in the coral surface microlayer Mar Ecol. Prog. Ser 33: 29-40

Smith. G. B. (1975). The 1971 red tide and its impact on certain reef communities in the mid-eastern Gulf of Mexico. Environ. Lett. 9: 141-152

Steidinger, K. A. (1979). Collection, enumeration and identification of free-living marine dinoflagellates. In: Taylor, D L., Seliger, H. H. (eds.) Toxic dinoflagellate blooms Elsevier/North-Holland, New York, p. 435-442

Steidinger, K. A. (1983). A re-evaluation of toxic dinoflagellate biology and ecology. Prog. phycol. Res. 2: 147-188

Steidinger, K. A., Baden, D. G. (1984). Toxic marine dinoflagellates. In: Spector, D. L. (ed.) Dinoflagellates. Academic Press, Orlando, p. 201-261

Yuki, K., Yoshimatsu, S. (1989). Two fish-killing species of Cochlodinium from Harima Nada, Seto Inland Sea, Japan. In: Okaichi, T., Anderson, D. M., Nemoto, T (eds.) Red tides: biology, environmental science, and toxicology. Elsevier, New York, p. 451-454

Manuscript first received: July 19, 1989

Revised version accepted: November 21, 1989 